\title{
Bentuk Fatis dalam Wacana Lisan Percakapan Keluarga Pada Masyarakat Melayu Jambi
}

\author{
Ade Rahima*, Irda Wahyuni \\ Program Studi Pendidikan Bahasa dan Sastra Indonesia, FKIP Universitas Batanghari Jambi \\ *Correspondence email: ade.rahima@unbari.ac.id, Irdawahyuni6@gmail.com
}

\begin{abstract}
This research aims to describe phatic forms in the oral text of family conversations in the Jambi Malay society at Kabupaten Tebo Jambi province. This study uses qualitative descriptive method, data collection techniques that are done with observation and recording. In this study, the data is in the form of phatic forms of the Jambi Malay language was taken from 2 families of 5 families who are native speakers of Jambi Malay in Kelurahan Pulau Temiang. Data are analyzed by using the distributional method. The results of this study show the forms of phatic of Jambi Malay in Kelurahan Pulau Temiang. It can be found there are three forms of phatic that include (1) phatic forms in the form of particles there are 30 data including 'kan', 'iyo', 'nak', 'dih', 'dek', (2) phatic in the form of the word there are 28 data including 'nelah', 'kan ko', 'kejaih', 'nonggok nelah', 'kalu', and (3) phatic in the form of phrases there are 2 data namely 'komsalam', 'salammelekom'.
\end{abstract}

Keywords: Jambi Malay language; sociolinguistics; phatic forms

\section{PENDAHULUAN}

Dengan adanya Bahasa derah merupakan hal yang sangat penting bagi perkembangan Bahasa Indonesia sebagai bahasa nasional, termasuk bahasa Melayu Jambi. Oleh karena itu, bahasa Melayu Jambi perlu dibina dan dikembangkan sesuai fungsinya. Salah satu fungsi terpenting bahasa Melayu Jambi dalam masyarakat adalah sebagai penghubung antar komunitas, sebagaimana disyaratkan oleh kebijakan bahasa nasional.

Salah satu fungsi bahasa yang sangat mendasar adalah sebagi instrumen untuk menjalin ahubungan dengan orang lain atau masyarakat sekitarnya. (Rofii dan Hasibuan, 2019). Hal ini dikarenakan manusia adalah makhluk sosial yang tidak dapat hidup sendiri. Bahasa akan digunakan sebagai alat untuk mengekspresikan dirinya kepada teman, keluarga atau sahabat. (Pernando dan Rahima, 2018).

Alat terpenting dalam masyarakat adalah bahasa. Bahasa daerah tidak hanya menjadi alat penghubung dalam masyarakat, tetapi juga menjadi simbol kebanggaan dan identitas daerah. Keberadaan bahasa daerah juga sangat penting dalam pengembangan bahasa Indonesia. Mengingat pentingnya bahasa itu, maka perlu dilakukan pembinaan dan pengembangan Bahasa Indonesia maupun Bahasa daerah.

Setiap daerah mempunyai ciri khas dan unsur bahasanya tersendiri yang biasa digunakan masyarakat sehari-hari dalam lingkungan daerah tertentu disebut Bahasa daerah. kebiasaan berkomunikasi dalam suatu masyarat mempunyai ciri khas tertentu. Pendapat tersebut diperkuat A. Rahima (2021) menjelaskan bahwa cara berkomunikasi seseorang atau suatu masyarakat adalah sesuatu yang menarik untuk diamati dan diteliti. Cara-cara berkomunikasi tersebut termasuk cara berdiam (tidak berbicara). Di Indonesia ada banyak bahasa daerah, salah satunya adalah bahasa Melayu Jambi.
Sebagian besar masyarakat melayu di Provinsi Jambi menggunakan dialek Bahasa melayu. Penelitian yang terkait wacana lisan dalam bahasa Melayu Jambi belum bayak dilakukan. Oleh karena itu, peneliti memfokuskan kajian ini pada wacana bahasa lisan khususnya wacana fatis.

Penelitian ini dilaksanakan dengana judul "Bentuk-Bentuk Fatis dalam Wacana Lisan Percakapan Keluarga pada Masyarakat Melayu Jambi Kabupaten Tebo Provinsi Jambi”. Berdasarkan uraian di atas maka dapat dijelaskan ada 5 alasan mengapa peneliti mengambil judul tersebut.

1. Alat berinteraksi yang sangat penting untuk menjalin komunikasi adalah Bahasa. Dengan adanya bahasa masyarakat dapat berkomunikasi dan terhubung dengan masyarakat yang lainnya.

2. Bahasa Melayu Jambi dikaji untuk mengembangkan BMJ ke masyarakat luas dan memperkaya pembendaharaan kata-kata, bentuk kata, dan fungsi kata dalam wacana fatis. Memahami dan mengenal suatu Bahasa daerah secara luas maka bisa mengetahui pelbagai macam faktor penting yang membedakan ciri khas dan struktur masyarakat di daerah tersebut.

3. Belum banyak kajian ilmiah khusus tentang bentukbentuk fatis dalam wacana lisan percakapan keluarga pada masyarakat Melayu Jambi

4. Kurangnya penelitian bahasa tentang bentuk-bentuk fatis dalam wacana lisan percakapan keluarga pada Masyarakat Melayu Jambi Penelitian ini, menggunakan kajian sosiolinguistik yaitu gabungan antara sosiologi dan linguistik. Sosiologi adalah ilmu yang berhubungan dengan orang-orang dalam masyarakat, lembaga-lembaganya, dan proses sosial yang terjadi di dalamnya. Adapun linguistik adalah ilmu yang membahas bahasa sebagai objek kajiannya. Jadi dapat dikatakan bahwa sosiolinguistik 
adalah ilmu yang membahas tentang bahasa dalam penggunaannya oleh masyarakat. (Chaer dan Agustina, 2010).

Berdasarkan hal tersebut penelitian ini difokuskan pada bentuk-bentuk fatis dalam wacana lisan percakapan keluarga pada masyarakat melayu Jambi

\section{METODE}

Metode penelitian ini adalah melakukan pendekatan yang dilakukan peneliti untuk memecahkan suatu masalah yang akan di teliti dengan cara mengumpulkan, mengolah dan menganalisis serta menyajikan data dalam penelitian ini. Jenis penelitian ini masuk kedalam penelitian deskriptif kualitatif yang bertujuan untuk mendeskripsikan fenomena yang terjadi secara nyata. Dalam penelitian ini, fenomena bahasa khususnya wacana fatis akan digambarkan sesuai kondisi data yang ditemukan (bersifat natural).

Data merupakan hal utama yang ada dalam suatu penelitian. Data dapat berbentuk lisan dan tulisan. Sumeber informasi yang terseleksi sesuai objek yang dikaji disebut data (Siswantoro, 2010). Dari pendapat ini dapat disimpulkan bahwa data merupakan syarat pokok dalam penelitian, untuk dijadikan sebagai bahan yang akan dianalisis. Oleh karena itu, kualitas dan ketepatan penggambilan data tergantung dari penguasaan konsep atau teori serta cara menyeleksi data tersebut.

Teknik pengumpulan data dilakukan bertujuan agar mendapatkan data yang diharapkan untuk menjawab masalah yang akan dikaji dalam penelitian ini. Adapun teknik pengumpulan data yang peneliti gunakan dalam penelitian ini yakni observasi, sadap rekam.

Teknik analisis data merupakan tahapan yang digunakan oleh peneliti di dalam penelitiannya. Menurut Mahsun (2006) tahapan penelitian yang perlu diperhatikan terkait tahapan analisis data, karena pada tahapan ini data yang menjadi objek kajian sudah harus jelas dan teridentifikasi dengan baik.

\section{HASIL DAN PEMBAHASAN}

Berdasarkan hasil temuan data yang diperoleh, maka dapat dijelaskan hasilnya secara rinci pada bagian ini. Hasil penelitian menunjukkan bahwa ada 60 data kategori bentuk fatis dalam wacana lisan. Data tersebut meliputi:

\section{Bentuk-Bentuk Partikel Fatis}

Berdasarkan analisis data penelitian diketahui bahwa bentuk-bentuk partikel fatis bahasa Melayu Jambi sesuai temuan data yakni:

'kan', 'iyo', 'nak', 'dih', 'dek', 'tang', 'ha', 'lak', 'do', 'lom', 'tuh', 'yo', 'oy', 'gi', 'lah', 'lak', 'go', 'mun', 'lu', 'moh', 'te', 'joh', 'koh', 'cam tu', 'e', 'nan', 'man', 'meang', 'alang'.

\section{Bentuk-Bentuk Kata Fatis}

Temuan data yang terkait bentuk kata fatis mencakup 30 kata yakni kata:

'nelah', 'kan ko', 'kejaih', 'nonggok nelah', 'kalu', 'gegalo', 'pelak ado', 'elok nyan', 'kete', 'bebenah', 'edak', 'tapo', 'cam tuh', 'kekeralap', 'gela ngan', 'kedian', 'pulak', 'kesulai', 'jelah', 'nelah', 'bena', 'halo', 'edak', 'bogok', 'meambor', 'pelak ado', 'anggak'an'.

\section{Bentuk-Bentuk Frasa Fatis}

Berdasarkan analisis data diperoleh hasil berupa bentuk-bentuk frasa fatis bahasa Melayu Jambi sebanyak 2 data yakni:

\section{'komsalam', 'salammelekom'.}

\section{Pembahasan}

Pada bagian ini, dibahas tentang bentuk-bentuk fatis dalam wacana lisan percakapan keluarga pada mayarakat Melayu Jambi

\section{Bentuk-Bentuk Partikel Fatis}

Mengacu pada teori Ramlan dalam Muslich (2014) menyatakan bahwa kata partikel adalah semua kata yang tidak termasuk golongan kata nominal dan ajektival. Selain itu mengacu pada teori menurut Moeliono (1998) menyatakan bahwa partikel penegas meliputi kata yang tidak tertakluk pada perubahan bentuk dan hanya berfungsi menampilkan unsur yang diiringinya. Kemudian menurut Kridalaksana (2008).

Kutipan 1

K1 (Y): 'Pesan ke nyo kan beko dak diapoon gela dek'

(Berpesan ke dia supaya dikerjakan nanti tidak dikerjakannya pula)

Partikel kan pada kutipan di atas dalam bahasa Melayu Jambi Kabupaten Tebo Provinsi Jambi termasuk ke dalam partikel fatis. Partikel kan termasuk ke dalam partikel fatis karena terletak pada tengah kalimat percakapan dan tidak tergolong ke dalam nomina. Analisis ini penulis mengacu berdasarkan teori Ramlan dalam Muslich (2014) menyatakan bahwa kata partikel adalah semua kata yang tidak termasuk golongan kata nominal dan ajektival. Selain itu juga mengacu pada teori Moeliono (1998) menyatakan partikel penegas meliputi kata yang tidak tertakluk pada perubahan bentuk dan hanya berfungsi menampilkan unsur yang diiringinya. Ada dan tidak adanya partikel kan dalam konstruksi kalimat tersebut tidak mengubah kalimat yang ada yakni pesan ke nyo beko dak diapoon gela dek. Hal ini diperkuat oleh teori Kridalaksana (2008) yang menyatakan bahwa partikel kan termasuk ke dalam partikel fatis. 


\section{Kutipan 2}

K1 (Y): 'nyo nak balek gela, balek nyo lah' (Dia mau pulang juga, pulang sendiri)

Partikel nak pada kutipan di atas dalam bahasa Melayu Jambi Kabupaten Tebo Provinsi Jambi termasuk ke dalam partikel fatis. Partikel nak termasuk ke dalam partikel fatis karena terletak di tengah kalimat percakapan dan tidak termasuk ke dalam nomina. Analisis ini mengacu pada teori Ramlan dalam Muslich (2014) menyatakan bahwa kata partikel adalah semua kata yang tidak termasuk golongan kata nominal dan ajektival. Kemudian menurut Moeliono (1998) juga menyatakan partikel penegas meliputi kata yang tidak tertakluk pada perubahan bentuk dan hanya berfungsi menampilkan unsur yang diiringinya.

\section{Bentuk-Bentuk Kata Fatis}

Berdasarkan hasil analisis data dan mengacu pada teori menurut Kridalaksana (2008) Kata fatis yaitu kata dalam sebuah kalimat yang bertugas untuk memulai, mempertahankan, dan mengukuhkan komunikasi atau mengukuhkan komunikasi antara pembicara dan pendengar dan biasanya terdapat dalam konteks dialog, lazimnya bentuk fatis digunakan dalam bentuk ragam lisan. Teori inilah yang dijadikan sebagai patokan analisis data kata fatis dalam penelitian ini.

\section{Kutipan 3}

K1 (S): 'enak nelah dak pakai tu, apo nan nak di berseheen' (enak sekali pakai itu, apa yang mau dibersihkan)

Kata nelah pada kutipan di atas dalam bahasa Melayu Jambi masyarakat Tebo termasuk ke dalam kata fatis karena kata tersebut berfungsi untuk mengukuhkan pembicaraan dalam percakapan lisan. Hal ini mengacu pada teori Kridalaksana (2008) yang menjelaskan bahwa dalam percakan, kata fatis bertugas untuk mengukuhkan atau mempertahankan komunikasi antara penutur dengan penanggap tutur yang terlibat dalam konteks dialog. Bentuk kata fatis ini biasanya digunakan dalam ragam lisan.

\section{Kutipan 4}

K1 (S): 'kan ko sungai meresah aek (Ini sungai deras air nya)

Kata kan ko pada kutipan di atas dalam bahasa Melayu Jambi Kabupaten Tebo Provinsi Jambi termasuk ke dalam kata fatis. Kata kan ko termasuk ke dalam kata fatis karena bentuk kata fatis kan ko digunakan untuk menekankan dalam menunjukkan suatu tempat. Analisis ini mengacu berdasarkan teori Kridalaksana (2008) Kata fatis adalah kata dalam kalimat yang fungsinya untuk memulai, mempertahankan dan memperkuat komunikasi antara pembicara dan pendengar dan biasanya ditemukan dalam konteks dialog, biasanya bentuk fatis digunakan dalam bentuk ragam lisan.

\section{Bentuk-Bentuk Frasa Fatis}

Berdasarkan analisis data dan mengacu pada teori Moeliono (1998) mengatakan Frasa adalah gabungan dua kata atau lebih yang bersifat nonpredikatif. Selanjutnya dikuatkan dengan teori Kridalaksana (2008) yang mengatakan ada beberapa frasa fatis yaitu: terima kasih, turut berduka cita, assalamualaikum, waalaikumsalam, insya allah, dengan hormat, hormat saya. Teori inilah yang dijadikan sebagai patokan analisis data kata fatis dalam penelitian ini.

\section{Kutipan 5}

K1 (Y): 'Komsalam, halo dak do elok suaro kaan $K a$ ' (Waalaikumsalam, halo tidak bagus suara kamu $\mathrm{Ka})$

Frasa Komsalam pada kutipan di atas dalam bahasa Melayu Jambi Kabupaten Tebo Provinsi Jambi termasuk ke dalam frasa fatis. Frasa komsalam termasuk ke dalam frasa fatis karena bentuk frasa fatis komsalam digunakan untuk membalas lawan bicara yang mengungkapkan assalamualaikum. Frasa waalaikumsalam dalam bahasa Indonesia ditulis menjadi satu kesatuan, walaupun begitu tidak mengubah arti kata tersebut. Karena itulah frasa waalaikumsalam digolongkan ke dalam frasa fatis. Hal ini diperkuat oleh teori Moeliono (1998) mengatakan Frasa adalah gabungan dua kata atau lebih yang bersifat nonpredikatif. Kemudian menurut Kridalaksana (2008) ada beberapa frasa fatis yaitu: terima kasih, turut berduka cita, assalamualaikum, waalaikumsalam, insya allah, dengan hormat, hormat saya.

\section{Kutipan 6 \\ K2 (S): 'Salammelekom Nyai' \\ (Asslamualaikum nyai)}

Frasa salammelekom pada kutipan di atas dalam bahasa Melayu Jambi Kabupaten Tebo Provinsi Jambi termasuk ke dalam frasa fatis. Frasa salammelekom termasuk ke dalam frasa fatis karena bentuk frasa fatis salammelekom (sssalamualaikum) merupakan ucapan salam yang berasal dari bahasa Arab. Frasa assalamualaikum terdiri dari dua kata, yaitu kata assalam (keselamatan) dan kata alaikum (atas kalian). Fatis assalamualaikum dalam bahasa Indonesia ditulis menjadi satu kesatuan, walaupun begitu tidak mengubah arti kata tersebut. Karena itulah fatis assalamualaikum digolongkan ke dalam frasa fatis. Hal ini sesui dengan teori Moeliono (1998) frasa adalah gabungan dua kata atau lebih yang bersifat nonpredikatif. Diperkuat oleh teori Kridalaksana (2008) yang mengatakan ada beberapa frasa fatis yaitu: terima kasih, turut berduka 
cita, assalamualaikum, waalaikumsalam, insya allah, dengan hormat, hormat saya.

\section{SIMPULAN}

Berdasarkan hasil penelitian dan pembahasan yang telah dijabarkan maka dapat disimpulkan bahwa:

Ada 3 (Tiga) bentuk-bentuk fatis yakni: partikel fatis, kata fatis, dan frasa fatis.

1. Bentuk-bentuk partikel fatis dalam wacana lisan percakapan keluarga pada masyrakat Melayu Jambi Kabupaten Tebo Provinsi Jambi terdapat 30 data yakni: 'kan', 'iyo', 'nak', 'dih', 'dek', 'tang', 'ha', 'lak', 'do', 'lom', 'tuh', 'yo', 'oy', 'gi', 'lah', 'lak', 'go', 'mun', 'lu', 'moh', 'te', 'joh', 'koh', 'cam tu', 'e', 'nan', 'man', 'meang', 'alang'.

2. Bentuk-bentuk kata fatis dalam wacana lisan percakapan keluarga pada masyrakat Melayu Jambi Kabupaten Tebo Provinsi Jambi terdapat 28 data yakni: 'nelah', 'kan ko', 'kejaih', 'nonggok nelah', 'kalu', 'gegalo', 'pelak ado', 'elok nyan', 'kete', 'bebenah', 'edak', 'tapo', 'cam tuh', 'kekeralap', 'gela ngan', 'kedian', 'pulak', 'kesulai', 'jelah', 'nelah', 'bena', 'halo', 'edak', 'bogok', 'meambor', 'pelak ado', 'anggak'an'.

3. Bentuk-bentuk frasa fatis dalam wacana lisan percakapan keluarga pada masyarakat Melayu Kabupaten Tebo Provinsi Jambi terdapat 2 data yakni: 'komsalam', 'salammelekom'.

Dari ketiga bentuk fatis di atas dapat di simpulkan secara keseluruhan bahwa, dari ketiga bentuk fatis, bentuk partikel fatis lebih dominan dan banyak ditemukan. Karena partikel fatis lebih sering dituturkan oleh penutur dalam percakapan keluarga $\mathrm{K} 1$ dan $\mathrm{K} 2$ pada masyarakat Kelurahan Pulau Temiang.

\section{DAFTAR PUSTAKA}

Ahmadi, R. (2014). Metodologi penelitian kualitatif. Yogyakarta: Ar-Ruzz Media.

Chaer, A., \& Agustina, L. (2004). Sosiolinguistik: perkenalan awal. Penerbit PT Rineka Cipta.

Kridalaksana, H. (1986). Kelas kata dalam bahasa Indonesia. Gramedia Pustaka Utama.

Mahsun, M. S. (2005). Metode penelitian bahasa. Jakarta: PT Raja Grafindo Persada.

Moeliono, A. M. (1992). Tata bahasa baku bahasa Indonesia.

Pernando, E., \& Rahima, A. (2017). Analisis Kohesi Leksikal dalam Majalah Patriotik LPM Universitas Batanghari Edisi XVI Juli-September Tahun 2016. Aksara: Jurnal Ilmiah Pendidikan Bahasa Dan Sastra Indonesia, 1(1), 1-10.

Rahima, A. (2021). Variasi Sapaan Ragam Akrab dan Ragam Santai Masyarakat Melayu Jambi dalam Komunikasi Verbal (Kajian Sosiolinguistik). Jurnal Ilmiah Dikdaya, 11(1), 1-6.

Ramlan, M. (1981). Ilmu bahasa Indonesia: sintaksis.
UP Karyono.

Rofii, A., \& Hasibuan, R. R. (2019). Interferensi Bahasa Batak Mandailing dalam Tuturan Berbahasa Indonesia Pada Acara Parpunguan Masyarakat Mandailing Kota Jambi. Aksara: Jurnal Ilmiah Pendidikan Bahasa Dan Sastra Indonesia, 3(1), 16-24.

Siswantoro Sunanda, A. (2004). Metode Penelitian Sastra. Surakarta: Universitas Muhammadiyah Press. 